\title{
Conundrum of religious mafia and legislation in South Africa: When does religion become a national threat? Reference to the Seven Angels Ministry
}

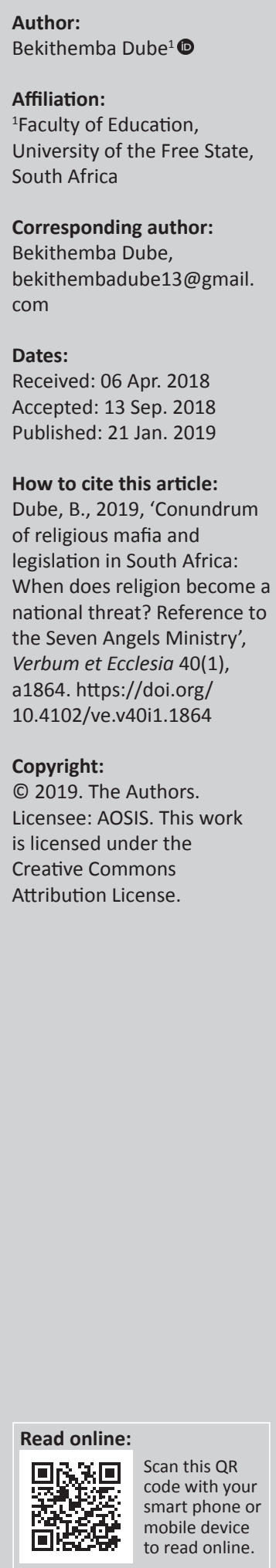

In this theoretical article, I analyse the hearing of the Seven Angels Ministry before the Commission for Religious and Linguistic Rights, and subsequent events that led to the killing of police and army officers at the Ngcobo Police Station. Informed by critical emancipatory research theory, I unpack the emerging nexus of the state, gender, legislation, religious freedom and human rights in the context of religious mafia. I answer two questions in relation to the Seven Angels Ministry and the Ngcobo killings: 'What are the tenets of a mafiarised religion?' and 'What can be done to mitigate the challenge?' I argue that a philosophical understanding of the constitution, education, gender and politics as practiced by the Seven Angels Ministry presents a trajectory of religion in contemporary society that must be problematised, unearthed and challenged to produce a world order that is responsive to societal needs and devoid of oppression and coloniality. I also argue that while religious freedom is a human right, it is important that legislation protects citizens from religious mafias, particularly when religious discourses negate schooling, promote gender inequality and emphasise constitutional delinquency.

Intradisciplinary and/or interdisciplinary implications: The article is interdisciplinary in the sense that it addresses the issues of education, constitutionalism, gender, child abuse and a need for a theology that challenges religious mafia exhibited by some religious movements. It calls for a change in legislation, and a different approach to theology as well as in curricula to address lived realities.

\section{Introduction}

In February 2018, the Ngcobo community witnessed a tragic incident, which involved the killing of police officers and a retired army officer inside the police station (Evans 2018). The tragedy was worsened by suspicions that the alleged killers were part of the Seven Angels Ministry, which had previously appeared before the Commission for the Promotion and Protection of the Rights of Cultural, Religious and Linguistic Communities (CRL Rights Commission) to answer to allegations of commercialising and 'mafiarising' religion, depriving children of education (SABC 2016) and hiding criminal elements within its shrine. A search at the church premises led to a shoot-out between the police and alleged criminals, and the deaths of the Mancoba brothers Xolisa, Thandazile and Philile - who had been part of the Seven Angels Ministry (Jordaan \& Mabuza 2018). An analysis of the hearing before the CRL (https://www.youtube.com/ watch? $\mathrm{v}=\mathrm{q} \times W P L g A-X \mathrm{rQ}$ ) (SABC 2016) in relation to the shooting incident at the police station and the hiding of alleged criminals on the shrine premises after the killings indicates that while religion has for a long time been perceived as an asset that promotes good citizenship, education, character formation and the peaceful resolution of conflict, it has also become a national threat by becoming a mafiarised, gendered space, with the potential to cause social unrest and delinquency. To buttress the foregoing argument, I quote the former police minister Fikile Mbalula, who described the Seven Angels Church as follows:

Police arrested suspected criminals in a satanic place masquerading as a church ... Those people are not praying for anything, but they have hypnotised abantu [people] ... There is no church there, but there is Satanism. (Evans 2018:1)

This description of religious practice in society identifies a need for religious scholars to question certain practices, with the intention of bringing the best out of religion, as expected by society. The killing of police members by people with religious connections reminds us that it is no longer safe to limit some religious practices and narratives to the private space (such as shrines and churches), 
if these practices have societal consequences. In addition, a need has developed to regulate religion, especially because some practices have become dangerous for society.

In cognisance of ambivalence about, and the contested definition of, religion (Schilderman 2015), I use the term 'religion' in this article to refer to a set of beliefs that people adhere to in obedience to a deity or divine being. Here, I use it more specifically in reference to the practices of the Seven Angels Ministry, whose quest is to find representation and identity in the post-colonial praxis of religion. While religion has positive and negative issues, I focus on negative (as perceived from a general understanding of conservative Christian theology) aspects, which I refer to as religious mafia. I use the term 'religious mafia' to explain the conduct and narratives of the Seven Angels Ministry and other likeminded religious organisations. The term 'mafia' is used in reference to the group of criminals known for using drugs and dangerous weapons to commit various crimes (Garzón 2008; Paoli 2004, 2007). However, in this article, I use it to refer to questionable religious practices or crimes committed using religious discourses. A religious mafia is characterised by the mental destabilisation of adherents, exorbitant financial demands, the perpetuation of gender inequality using religious narratives, the indoctrination of children, the expression of antisocial sentiments, incidents of breaking the law and disturbing order, and the infiltration of public authorities (Gest \& Guyard 1995:15). After analysing the Ngcobo shooting closely, I agree with Lunn (2009:939) that, when religion is not regulated, it can be an 'impediment to economic advancement, and irrelevant for modern societies'. Therefore, as argued by Beyers (2014:1), religion, especially the mafiarised type, needs to be put on the table again for debate; the church or religious players need to engage with social issues and find new ways of expressing neighbourly love. In response to this call, I propose various themes that emanate from religious mafiarisation. To do so, I begin by highlighting the framing of the article, which is critical emancipatory research (CER).

\section{Theoretical framing: Critical emancipatory research}

There have been debates on who mooted the idea first, but CER can be traced to the Frankfurt School of 1923. McKernan (2013:424) lists the 1871 narrative of Emmanuel Kant, a German philosopher, as a prominent narrative on the rise of CER, while McLaughlin (1999:109) believes that it was a product of a 'Marxist think tank founded by a wealthy son of a German millionaire, Mr Weil, who helped the Frankfurt School to create an innovative brand of philosophical oriented radical social science'. Wiggershaus (1994:39) is of the view that the members of the Frankfurt School represented 'Social Democratic governmental benevolence, a group of intellectual communists with a small " $\mathrm{c}$ " whose commitment to Marxism was clear to change oppressive and dehumanising conditions'. Grounded in Marxist-Leninist thinking (McKernan 2013:424), the theory 'emerged not only out of suspicions in the academy but also out of wider social movements and struggles against oppression which have found a voice in the academy [and religion]' (Carrette \& Keller 1999:22-23). It is a theory that argues that 'social groups are capable of transforming society' (Held 1999:250), especially from conditions that dehumanise people and render others as sub-humans who are susceptible to abuse by the strongest members of society. It is 'oriented towards the gradual reformation of the oppressive status quo' (Ngwenyama 1990:3), which is what I seek to do in relation to the Ngcobo Seven Angels Ministry and similar religious organisations.

I have chosen to frame this article in CER because it 'empower[s] the less advantaged in terms of being able to take an active agent role in social change' (Mertens 2007:222). Furthermore, it 'looks at, exposes, and questions hegemony, traditional power assumptions held about relationships, groups, communities, societies, and organisations to promote social change' (Given 2008:140). Through examining the Ngcobo police shooting and the Seven Angels Ministry, my aim is to contribute to solving the problem of religious mafia through engaging in 'critical thinking and the use of knowledge which is free from superstition and prejudice' (Steinvorth 2008:400) and, as suggested by Madison (2005:210), to 'free man from all unnecessary domination'. Finally, through CER, the victims of the Seven Angels Ministry could be empowered through counselling to transform the status quo and emancipate themselves from ongoing oppression (Ponterotto 2005:131), and recover from the traumas caused by the religious mafia.

In the following section, I highlight various themes emerging from the Ngcobo Seven Angels Ministry in the hope that these themes will emancipate society and enable the government to identify cultic and destructive tendencies and mafias disguised as religion.

\section{Emerging issues from the Ngcobo Seven Angels Ministry: Problematising cultic religion}

This section covers the theme that emerged from the discussion of the CRL and the Seven Angels Ministry, and the aftermath of the police shooting at the Ngcobo Police Station.

\section{Constitutional delinquency}

One of the features of a movement that is a religious mafia is its pursuit of a left-wing political orientation (a group of people who are anti-establishment and often opposed to the government of the day). Often, members believe that their views are absolute and right, and a direct revelation from God, which is also one of the characteristics of fundamentalist religious groups. Under these auspices, the adherents of a religious mafia become extremist, characterised by resistance to the political practices of the day (Gregg 2016:346). An underlying resistance to political powers, as shown by the Seven Angels Ministry, is not only fundamentalistic, or representative of religious mafia, but it may reflect an anti- 
establishment world view. While some religious groups that align themselves with the Christian faith, or claim to be of the Christian faith, do not necessarily have copies of the constitution in their church, the general teachings of the Bible is that those in authority must be respected (see 1 Tim. 4), and the laws of the country must be obeyed. However, in the case of the Seven Angels Ministry, it seems that ministry leaders had knowledge of the constitution, but deliberately chose to disregard it, as they believe that it comes from the devil. In this regard, the existence of the Seven Angels Ministry must be considered in light of post-colonial growth of local beliefs and the right to freedom of religion. This is, unfortunately in some cases, characterised by the use of religion to commit crimes or embrace a superstitious ideology (which mistakenly ascribes certain happenings to the supernatural) which claims that adherents are better than everyone else. The behaviour of the leaders of the Seven Angels Ministry is similar to that witnessed at Jonestown, when Jim Jones isolated his followers from outside media and subjected them to near-constant haranguing. He used propaganda to blackmail the United States government and members' families. The news media, according to Jones, sought to destroy his community (VanDeCarr 2003:24); Chidester (2003) describes this phenomenon as strategic distancing, while Bradley (2012:1) describes it as Christian-failure narrative. Gregg (2016) notes that mafiarised religion chooses various means to reinforce and defend its interpretation of the faith, including isolation, political activism and violence. At Jonestown, the consequences were so dire that 918 people lost their lives.

We should look closely at the words of the Seven Angels Ministry before the CRL exposed their tendency to be a religious mafia and to practice constitutional delinquency, including proclamations such as the following:

We are above the constitution of South African constitution and it will perish. (SABC 2016)

There is an angel that left heaven by the name of Lucifer whom we have come to seek on earth. He has come and has breathed into the constitution of South Africa and its schools. He took schools and the constitution to himself ... we also say that the people must not listen to the constitution because it is controlled by the devil. (SABC 2016)

Regarding the foregoing, I agree with Bradley (2012:1), who points out that some church leaders deploy negative portrayals of the church, characterising it as 'failing', 'in crisis' or otherwise not living up to Christian standards, in order to motivate their followers to divert from the norm. In this case, the church leaders' disregard of and negative attitude to the constitution poses a national threat that must not be rejected as frivolous. It is this disregard of the constitution that could have led to the shooting at the Ngcobo Police Station, because, according to the view of the Seven Angels Ministry, the church is above the constitution.

This implies that ideological narratives which subvert constitutional arrangements are the order of the day in religious mafias; among these narratives are references to the
South African constitution as evil and claims that the constitution has its roots in the devil. Such approaches often facilitate the achievement of politics of representation and recognition through negativity; that is, seeking recognition through delinquency. Ndlovu-Gatsheni (2015:21) describes it as a crisis of imagination regarding liberation, freedom and development in some post-colonial religious practices, such as beliefs that one is above the law by virtue of religious powers or positioning, as is claimed by the Seven Angels Ministry. In this milieu, CER is ideal for challenging this crisis of imagination, through the adoption of a 'critical reflection that can effect change or improve the action' (Kreber 2005:397), not only for Seven Angels Ministry adherents, but also for the state and society.

While the Seven Angels Ministry exhibits obvious tendencies of constitutional delinquency, it is unfortunate that the South African parliament does not see this as a threat to the state and the community. A parliamentary spokesperson was cited by Jordaan and Mabuza (2018) as saying:

What happened in Ngcobo Police Station is a pure criminal matter which is being dealt with by the law enforcement agencies. (p. 1)

Those of us who have studied religion and its impact on society can see that the connection between the Ngcobo shooting and the Seven Angels Ministry signifies a mafia with religious backing. Therefore, by placing the Ngcobo incident in a criminal space, parliament is taking a minimalistic approach to understanding the impact of religion when it is mafiarised. Incidents involving Boko Haram should serve as a lesson to parliament in relation to unregulated religious practices that represent more than criminality. With this in mind, I am of the view that constitutional delinquency, and the subsequent shooting at the Ngcobo Police Station, should be interpreted as a national threat and as a violation of human rights. I call for legislation to be updated in relation to freedom of religion, in order to protect the state and the community from religious mafias or criminals who use religion as a cover to commit crimes.

In light of the statement from parliament, and that of the Seven Angels Ministry on the constitution, the paradox is that the Seven Angels Ministry practices constitutional delinquency and regards the constitution as evil - the same constitution that grants them freedom of religion. Yet, parliament hesitates to amend the constitution, thereby seeming to protect the rights of the Seven Angels Ministry at the expense of abused citizens. In this regard, I agree with Thoko Mkhwanazi-Xaluva, the commissioner and chair of CRL, who said that parliament must be held to account for failing to prevent the tragedy, including the massacre of security officials at the Ngcobo Police Station in the Eastern Cape, by criminals who were allegedly members of a cult church in the area (Jordaan \& Mabuza 2018). In brief, the theme that emerges and serves as a lesson to the state and the community is that religious mafias manifest themselves in practicing constitutional delinquency. 


\section{A disregard of education and children's rights}

In addition to practising constitutional delinquency, the Seven Angels Ministry disregards education and thereby negates human rights by depriving learners of the benefits associated with schooling. To religious mafia, education is evil, as it indoctrinates people with anti-God discourses. As a way of protecting children from distorting narratives, a withdrawal from education becomes inevitable and, consequently, the bill of rights for children is violated.

According to Anderson (2018), the church that sheltered the alleged police attackers was no stranger to controversy. In 2016, police had carried out a raid there to rescue 18 children who had allegedly been prevented from attending school. Here, too, the behaviour of the Seven Angels Ministry is similar to that of Jim Jones, who, at Jonestown, forced members to turn over all their material assets, including their children (Klenetsky 1983:26), who became religious property. The Seven Angels Ministry did not hide their ideology regarding education; this is what Banele, the spokesperson of the group, said to the SABC (2016):

We are saying as Seven Angelic Ministries, firstly I am not a pastor; I am an angel from heaven, seated at the right of the Father. We say that children should not go to schools because the devil has intervened with the schools. We will continue to tell the learners to stop going to school and not to listen to the constitution because the devil has taken over the schools.

This deliberately negative attitude towards education means that adherents' children are illiterate and unemployable. Negativity towards schooling for children, and the rejection of schooling, is also present among the adult community of the ministry. Some adherents resigned from the teaching profession, and the logical assumption is that educators among the adherents saw education as evil, deciding that they could not participate in it after their alleged enlightenment. While it is not a crime for adults to resign from teaching for religious reasons, for children, this attitude presents serious trajectories, an abuse of their rights as children and the destruction of social cohesion. Gregg (2016:346) explains that religious mafia groups often decide to isolate themselves from a perceived threat; this course of action could include physically isolating themselves, creating separate communities, breaking ties with mainstream religion and forming new sects or denominations, or socially isolating the group from the broader society by creating parallel institutions, such as schools, clinics, stores and so on.

The stance of the Seven Angels Ministry regarding education, particularly if it means children are deprived of their basic right to education, must be problematised with a lens of CER, because the theory is 'opposed to any [religious] practices that undermine the rights of students' (Nkoane 2010:113114). In problematising some religious teachings, I become part of society's struggle, as suggested by Bottoms et al. (1995:3), to protect children's rights and welfare when these are threatened by religious beliefs and practices. In this regard, a law should be passed that prohibits religious communities from depriving children of their basic rights, such as education, because of religious convictions.

\section{Extortionist tendencies}

Religious mafia movements generally exhibit extortionist tendencies, such as manipulating religious adherents to give up all their possessions through promises that they will receive greater returns, or to prove their obedience to God. Unfortunately, the money donated by church members is used mainly to fund the lavish lifestyles of church leaders. Applying this practice to the Seven Angels Ministry, the lavish lifestyle of the Mangcoba brothers was made possible and maintained through the philanthropic giving of church members. Some gave every cent of their savings and pensions, and even their cars. Larsen (2010) explains that Jim Jones gave his followers hope, and made them believe that change was possible; it became easy for church members to entrust their wealth to Jones. When asked by the CRL how they used the money given to them by church members, the spokesperson of the Seven Angels Ministry said:

Well, when one gives, there are those things that are said to be needs, needs like traveling to a certain place to preach the gospel. We buy clothes for the less fortunate who seem not to have clothes for going to church. The money is used to go buy food and clothes for the less fortunate. We don't keep the money to ourselves. In the past we used to save money at the bank but now that God has said these are the end times, we don't any longer. We operate by getting the money hard cash and using it for the needs. We cannot disclose publicly the offering of congregants and tell the details of who exactly give what to the church and what influenced them to make such offerings. (SABC 2016)

In South Africa, it is not exceptional for religious organisations to refuse to disclose their financial status. The CRL (2015) notes that extortionist religious groups exhibit a tendency to refuse to take prescribed oaths or to provide documents that are required, including financial statements, Annual General Meeting minutes, constitutions, codes of conduct, disciplinary codes, statements of faith, information about signatories to bank accounts, deeds or leases of the land they operate from and organograms. This refusal leads to some religious groups being perceived as mafias. With this tendency in mind, Thinane-Epondo (2015) believes that emerging ministries are run like insurance companies that claim spiritual powers in a sanctimonious way. Given that many members of the Seven Angels Ministry are unemployed, how is the ministry financed? Could the raid at the police station and the plans to bomb an Automated Teller Machine be linked to the need to obtain money for the ministry (Ngcukana \& Fengu 2018)? Can it be proved that the ministry did not commit other crimes in the Eastern Cape and surroundings? Answers to these questions could confirm that mafiarised religion poses a threat to the state; hence, legislation to regulate churches is essential to protect citizens.

\section{A threat to national security}

All over the world, it is becoming more common for religious adherents to be involved in contemporary security affairs. 
Many conflicts or threats, for instance, extorting money, rejecting schooling and practicing constitutional delinquency, are driven by groups of strong faith (Wœver 2007:209). As indicated above, mafiarised religions assume left-wing political ideologies, which often pose a threat to the peace and stability of nations. The shooting at the police station and finding the alleged perpetrators hiding at the shrine premises lead one to ask how safe the state is from a mafiarised religion. According to Magwedze (2018), police confirmed that firearms which had been stolen during the murder of officers at the Ngcobo Police Station were recovered at the church at Nyanda village, where a cult had been living. This was confirmed by the police spokesperson, Vuyo Mhaga, who said that the police were concerned that the church was housing criminals (Magwedze 2018; Spies 2018). Fuzile (2018) reported that the police task team, which comprised the Hawks and other units of the police, had arrested four Mancoba Seven Angels Ministry members who are alleged to be linked to the murder case of an UMzimkhulu church leader and his wife. Proving that the ministry poses a national threat, one of the Seven Angels Ministry leaders noted before the CRL hearing:

As Angelic ministries, we will not be silent until we have the whole world on our side as it was from the beginning. (SABC 2016)

Considering this statement by a Seven Angels Ministry representative, Wœver (2007:212) is correct in pointing out that movements such as that of the Seven Angels Ministry believe they are 'more devout' than others, which is confirmed by their reference to themselves as angels. They do not possess an original theology; rather, they are political activists locked in a struggle for an alternative relationship between religion and politics. If this is the case, it is critical that religious groups such as the Seven Angels Ministry be placed under scrutiny, not to infringe on their religious rights and freedoms, but to ensure that their narratives do not pose a threat to society or even the state. It is known that some religious groups, such as Al-Qaida, Boko Haram and the Islamic State of Iraq and Syria, have become a thorn in the flesh of many nations. In this regard, South Africa must acknowledge that some religious practices are dangerous, especially when they appear to operate in extraordinary ways, compared to the generally expected religious behaviour. When such ministries fail to show respect for constitutionalism, they do not respect human rights and fail to show love for people. Thus, through the lens of CER, certain religious practices must be challenged and eliminated, especially when they exhibit tenets that could bring religion into disrepute, such as disregarding the constitution, and the general conduct of the Seven Angels Ministry and likeminded organisations.

\section{Gender insensitive}

From its formation, the ministry leadership composition of the Seven Angels Ministry (all men) had much to say about the position and value of women in a mafiarised religious ministry. Farley (2008:48) reveals that 'women remain blatantly excluded from leadership and decisionmaking roles in tribes, in civil government, and in churches, temples, and mosques'. In the leadership arrangement of the Seven Angels Ministry, there is a clear indication that women lack representation, implying that the leaders do not consider the needs and expectations of women to be important. Thus, the Seven Angels Ministry promotes patriarchal tendencies and various human rights abuses against women (Alexander \& Alexander 2001:133). In elaborating on the extent to which women are abused in the Seven Angels Ministry, former police minister Mbalula, as quoted by Dayiman and Ntshobane (2018), said:

The women have been brainwashed. They are just walking dead. That thing that has captured their minds is not a church, but is a satanist place of witchcraft. (p. 1)

Given this claim by Mbalula, I agree with Owusu-Ansah (2016), that:

[...] denying women the right to be themselves and the rights to pursue careers or work outside the home and confining them to a specific space also could be termed as psychological violence. (p. 3)

Mbalula's description of the church shows that women have no rights at all - they are as good as walking dead, they have been brainwashed and their independent thinking has been destroyed. It also means that women in the church can only interpret the reality of life through the lens of the Seven Angels Ministry's men, denoting that the abuse of women is the order of the day. This attitude means that the Christianity that characterised the past has been lost (Beyers 2014:1); historically, the Christian faith cared for the poor, championed the righteous, enjoyed good social standing, promoted humility and preached equality. In brief, a collective responsibility is essential if we are to redress the imbalance in relation to the way women are treated in society, especially under the auspices of religion. Owusu-Ansah (2016:4) claims that 'violence against women and girls can be reduced and consequently eliminated only through fundamental social and attitudinal changes at the family, community, state and international levels'.

\section{Superhuman mentality}

From the inquiry by the CRL, it is clear that the Seven Angels Ministry's brothers, and adherents in general, consider themselves to be superior to ordinary human beings. This idea creates or opens a way for some people to abuse others. During the trial of the police murder, one of the accused noted that (African News Agency [ANA] 2018):

I believed Thandazile because he said he was the son of the Lord. (p. 1)

In addition, before the commission, a Seven Angels Ministry representative told the CRL that they were angels and superhuman:

We are saying as Seven Angelic Ministries, firstly I am not a pastor; I am an angel from heaven, seated at the right of the father ... We have met with him [satan] on Saturday when I went 
to spirit world in the principalities of darkness. Where he asked me why we are looking for him because the seven of us are looking for him. (SABC 2016)

The belief that religious leaders are more important than other people is one of the characteristics of an abusive religion, and this belief can be dangerous. Elevating religious leaders to a status higher than that of ordinary human beings relates to an observation made by Enroth (1992:41) that religious leaders are holders of spiritual power; and unfortunately, such power is often abused or used to propagate evil in society. Mbalula describes this abuse as evil and involving witchcraft (Dayiman \& Ntshobane 2018). The unfortunates, in most cases, are the religious adherents, who believe that their leaders are supernatural, even though some leaders abuse them. In fact, considering their behaviour, one might argue that their superstitious beliefs inspire them to view leaders as supernatural. Therefore, the struggle that religious scholars have is to help the abused, mistreated and dehumanised when the victims believe that their state and interaction with such religious leaders is a blessing. Cognisant of this challenge, I believe that there is a need for an awakening of consciousness and an awareness of social injustice within religious discourse (Stinson 2009:506). Thus, as Alvesson and Willmott (1992:436) argue, there is a need to 'challenge any forms of knowledge and practices that serve to sustain the illusion of oppression and to replace with an emancipatory one'.

\section{What can be done to redress the trajectories of cultic tendencies?}

To answer this question in light of the Seven Angels Ministry and like-minded religious groups, I concur with the observation of Bottoms et al. (1995:109) that ' $[I] \mathrm{n}$ the long run, society should find ways to protect people [against] religion-related abuse, and help religion evolve in the direction of the better treatment of people'. In addition, I engage in a struggle, as Alvesson and Willmott (1992:432) propose, 'through which individuals and groups become freed from suppressive social and ideological situations, particularly those that place socially unnecessary restrictions upon development and emancipation of human consciousness'. My first suggestion for achieving this aim is amending the constitution.

\section{Amending the constitution}

The Constitution of the Republic of South Africa (1996:13) states that 'everyone has the right to freedom of conscience, religion, thought, belief, and opinion'. In addition, Section 31(1) (a) states:

Persons belonging to a cultural, religious, or linguistic community may not be denied the right

(a) to enjoy their culture, practise their religion, and use their language. (p. 13)

While this stipulation is appreciated, there is a need to rethink the rights it conveys, in light of the practices of the Seven
Angels Ministry and like-minded religious groups, which portray constitutionally delinquent tendencies, extortion and the abuse of women and children. Amending the constitution to limit abuses by or through religion could eliminate 'situations that limit freedom ... where barriers have been dissolved and people can control the direction of their own lives' (Ryan 1998:260). Thus, I disagree with Hertzke (2012), who argues that 'when governments relax restrictions on religion and treat all groups equally, greater societal tolerance and civility ensue, leading to positive cycles where groups channel energies and competition in civil society pursuits'. The Seven Angels Ministry representative at the CRL also declared that:

We are above the constitution of South African constitution and it will perish. (SABC 2016)

In light of this statement, it would be unfortunate if parliament, the custodian of the law, is reluctant to rethink legislation. A parliamentary spokesman, quoted by Jordaan and Mabuza (2018), said that the state cannot prescribe when it comes to people's beliefs and religious convictions. However, the issue is not about prescribing, as claimed by the parliamentary spokesperson, but about a call to enact laws to protect church members from abusive leaders. The religious mafia is not always exposed and reported, as criminal elements are, yet they are dangerous because their behaviour has the impetus to destroy the social fabric of society. Amending the constitution would ensure the prosecution of church leaders, even in the absence of complaints. (Complaints are unlikely because religious mafia groups often make their victims voiceless). For prosecution to be possible, the community must help to identify and define abnormal (though contested) behaviour among religious groups in terms of its relationship with the law and human rights (Mutangi 2011:528).

\section{Regulation of churches}

The mafiarisation of religion can be mitigated when religion and its practices are regulated. This regulation does not imply the state taking over control of religious matters; instead, religion can be controlled by religious bodies that represent religious players. In addition to the CRL, there should be a religious body comprising people who represent different churches to expose religious practices that are not consistent with what is normal and usual. This could mean the registration of all churches, and pastors, priests and traditional leaders, so that their practices are clear and traceable. This would avoid a repeat of the situation where the Seven Angels Ministry spokesperson declared:

We are not registered in any form, so what was required of us we do not have, even the banking details. (SABC 2016)

Avoiding registration and hiding information about a church's financial status helps the Seven Angels Ministry and like-minded organisations to avoid accountability, because there is no evidence that money is being abused, or that their practices are inconsistent with regulatory requirements. 
Thus, it is critical to regulate religious bodies so that practices by churches are mitigated and any threats they pose to the state and community at large are eliminated. In addition to religious regulation, introducing compulsory basic training for religious leaders on issues of religious governance, human rights, education and community development at state-registered institutions would go a long way to addressing the problems caused by some religious practices in South Africa.

In brief, I agree with the CRL that there is no law to prevent anyone from starting a cult in South Africa. The CRL's position is that if it had been granted the power to license and therefore control - all religions and religious activities in South Africa, cults like the Seven Angels Ministry would not exist (Destiny Connect 2018), or their practices would be confined by principles guaranteeing social justice, emancipation and the respect for human rights.

\section{Reintroduction of religion in schools}

One of the mistakes that South Africa has made was downplaying the role of religion in the public school curriculum. The current coverage of religion under life orientation is too limited to address the problems caused by some religious institutions in society, even though religion is a component of social life and of politics (Bloom, Arikan \& Sommer 2014). Many developed countries have retained religion in their curricula, and this approach should be considered by curriculum planners in South Africa. As long as people in South Africa practice religion, there is a need to teach and learn about religion. The Seven Angels Ministry incident serves to remind curriculum planners and religious scholars that the study of religion cannot be left to a few people who may distort religious narratives to commit crimes. As long as people lack an understanding of religion, exploitation and abuse in the context of religion will continue, because religious knowledge, such as religious laws and teachings from sacred books such as the Bible, becomes the privilege of a few. Thus, it is important, in light of the Ngcobo incident, that we rethink the position of religion in the curriculum because some religious practices are becoming socially pathological.

\section{Strength of the article}

This article is critical in the sense that it has exposed religious mafia systems. The themes discussed here can serve as a yardstick by which society in general, and religious people in particular, can identify religious mafias and deal with them as soon as possible before their practices escalate to the level of a national threat. The article is also important in the sense that it calls for the regulation of religious activities in accordance with the constitution, and ensuring human rights. While abuses or criminality sanctioned by religion were witnessed at Ngcobo, it does not mean that its effects remain within the confines of the Ngcobo community and church members. In fact, abusive religious tendencies have a snowball effect, the effects of which, when not problematised, can escalate and affect many people. With this in mind, I believe that the trajectories and the solutions suggested here can be applied to other contexts where there is abuse and criminality in the name of religion. In brief, the strength of the article is that it arms people to unmute, expose, challenge and resist religious mafia practices. Through this article, I open an academic space where people can start to problematise religion, not with the intention of eliminating it, but to enhance its validity in society and to cause transformation, emancipation and the improvement of the human condition. Thus, I argue that religion, when practiced within the confines of love, justice and equality, has the impetus to make the world a better place for all, though it does not imply that opportunists, mafia groups and criminals cannot abuse religion.

\section{Limitations}

The weakness of this article is that it assumes that all the practices of the Seven Angels Ministry are abusive and bad, yet this may not be true. The article concentrated on the rogue elements of the Seven Angels Ministry, which limit the article, because it does not matter how thin one slices the bread, it always has two sides. Therefore, I call on other scholars to problematise my approach, with the intention of bringing together religious players to improve the human condition. The article is theoretical and does not use empirical data gathered from victims of church abuses, who might have a different story from what is being portrayed in the media.

\section{Conclusion}

This theoretical article analysed the hearing of the Seven Angels Ministry before the CRL, and the aftermath of the police shooting, which connected the ministry to mafiarisation. I expose various themes that can serve to explain how abusive religions can be identified in society. I go further to suggest ways in which the religious mafia can be addressed in the South African context. I recommend the regulation of churches, the amendment of the constitution and the reintroduction of religion in schools. Through these actions, religion can regain its beautiful space in society and be characterised by social justice, love, emancipation and the improvement of the human condition.

\section{Acknowledgements}

The author thanks the Faculty of Education, QwaQwa Campus.

\section{Competing interests}

The author declares that he has no financial or personal relationships that may have inappropriately influenced him in writing this article.

\section{References}

African News Agency (ANA), 2018, 'Ngcobo police shooting: Suspects reveal all in bai hearing', IOL News, viewed 20 March 2018, from https://www.iol.co.za/news/ south-africa/eastern-cape/ngcobo-police-shooting-suspects-reveal-all-in-bailhearing-13663318 
Alexander, K. \& Alexander, D., 2001, American public school law, 5th edn., Wadsworth Publishing, Belmont, CA.

Alvesson, M. \& Willmott, H., 1992, 'On the idea of emancipation, management and organization studies', Academic of Management Review 17(3), 432-454. https:// doi.org/10.5465/amr.1992.4281977

Anderson, N., 2018, 'Ngcobo police shooting: Suspects killed after Friday night church shootout', The South African, viewed 02 March 2018, from www.thesouthafrican. com/ngcobo-police-shooting-suspects-killed/

Beyers, J., 2014, 'The church and the secular: The effect of post-secular on Christianity', HTS Teologiese Studies/Theological Studies 70(1), 1-12. https://doi.org/10.4102/ hts.v70i1.2605

Bloom, P.B.-N., Arikan, G. \& Sommer, U., 2014, 'Globalisation, threat and religious freedom', Political Science 62(22), 273-291. https://doi.org/10.1111/1467 9248.12060

Bottoms, B.L., Shaver, P.R., Goodman, G.S. \& Qin, J., 1995, 'In the name of God. A profile of religion-related child abuse', Journal of Social Issues 51(2), 85-111. https://doi.org/10.1111/j.1540-4560.1995.tb01325.x

Bradley, R.E., 2012, 'Bad news about the good news. The construction of Christianfailure narrative', Journal of Religion and Society 14(2012), 1-19.

Carrette, J. \& Keller, M., 1999, 'Religion, orientation and critical theory: Race, gender and sexuality at the 1998 Lambeth Conference', Theology and Sexuality 6(11), 21-43. https://doi.org/10.1177/135583589900601103

Chidester, D., 2003, Salvation and suicide: Jim Jones, The Peoples' Temple, and Jonestown, Indiana University Press, Bloomington, IN

Commission of Religious and Linguistic Rights (CRL), 2015, CRL Rights Commission's preliminary report of the hearings on commercialisation of religion and abuse of people's belief systems, viewed 20 March 2018, from http://www.crlcommission. people's belief systems, viewed 20 March 2018 , from http://www.crlcommission. Commercialization $\% 20$ of $\% 20$ Religion $\% 20$ and $\% 20$ abuse $\% 20$ of $\% 20$ people's $\% 20$ belief $\% 20$ systems.pdf

Dayiman, M. \& Ntshobane, S., 2018, “"We didn't know," say Ngcobo church followers', SowetanLive, viewed 13 March 2018, from www.sowetanlive.co.za/news/ southafrica/2018-02-26-we-didnt-know-say-church-followers/

Destiny Connect, 2018, 'Freedom of religion. South Africa calls for commission of inquiry into Ngcobo massacre', viewed 12 March 2018, from www.destinyconnect. com/2018/03/13/freedom-religion-sa-calls-commission-of-inquiry-ngcobomassacre

Enroth, R.M., 1992, Churches that abuse, Zondervan, Grand Rapids, MI.

Evans, J., 2018, "Ngcobo massacre: Mbalula brands shoot-out church "satanic", News24, viewed 01 March 2018, from www.news24.com/southafrica/news/ ngcobo-massarce-mbalula-brands-shoot-out-church-satanic-20180224

Farley, M., 2008, Just love. A framework for Christian sexual ethics, Continuum, New York.

Fuzile, B., 2018, 'Ngcobo shooting suspects in court for Umzimkulu double murder', Dispatch Live, viewed 29 March 2018, from www.dispatchlive.co.za/news/201803-05-ngcobo-shooting-suspects-in-court-for-double-murder

Garzón, J.C., 2008, Mafia \& Co. The criminal networks in Mexico, Brazil and Colombia Woodrow Wilson International Center for Scholars, Washington, DC.

Gest, A. \& Guyard, J., 1995, Reports made in the name of the board of inquiry into sects, 22 December, viewed 01 August 2018 from http://www.cftf.com/french/ les-sects-en-france/cults

Given, L.M. (ed.), 2008, The Sage encyclopaedia of quantitative research methods, Sage, London.

Gregg, H.S., 2016, 'Three theories of religious activism and violence: Social movements, fundamentalists, and apocalyptic warriors', Terrorism and Political Violence 28(2016), 338-360. https://doi.org/10.1080/09546553.20 14.918879

Held, D., 1999, Introduction to critical theory. Horkheimer to Habermas, Herder and Herder, London.

Hertzke, A.D., 2012, 'Religious freedom in the world today: Paradox and promise', Acta 17(2012), 1-12.

Jordaan, N. \& Mabuza, E., 2018, 'Seven Angels Ministry, site of a deadly shoot-out on Friday, is "extremist", Business Day, viewed 20 March 2018, from www. businesslive.co.za/bd/national/2018/02/2018-seven-angels-ministry-site-of-adeadly-shoot-out-on-friday-is-extremist

Klenetsky, K., 1983, 'How Jonestown happened under Carter or Mondale', Executive Intelligence Review 10(49), 24-26.

Kreber, C., 2005, 'Charting a critical course on the scholarship of university teaching movement', Studies in Higher Education 30(4), 389-405. https://doi. org/10.1080/03075070500160095

Larsen, L.E., 2010, 'What went wrong with the Peoples Temple? A closer look at Jim Jones and the Peoples Temple', Master's thesis, School of Mission and Theology, Stavanger, Norway.
Lunn, J., 2009, 'The role of religion, spirituality and faith in devil: A critical theory approach', Third World Quarterly 30(5), 937-951. https://doi. theory approach, Third World

Madison, G., 2005, 'Habermas' psychoanalysis and emancipation', Existential Analysis $16(2), 209-220$.

Magwedze, H., 2018, 'Ngcobo church remains sealed after police shootout', Eyewitness News, viewed 12 March 2018, from https://ewn.co.za/2018/02/26/ ngcobo-church-remains-sealed-after-police-shootout

McKernan, J.A., 2013, 'The origins of critical theory in education: Fabian socialism as social reconstructionism in nineteenth-century Britain', British Journal of Educational Studies 61(4), 417-433. https://doi.org/10.1080/00071005.2013.824947

McLaughlin, N., 1999, 'Origin myths in the social sciences: Fromm, the Frankfurt School and the emergence of critical theory', Canadian Journal of Sociology 24(1), 109-139. https://doi.org/10.2307/3341480

Mertens, D.N., 2007, 'Transformative paradigm: Mixed methods and social justice', Journal of Mixed Methods Research 1(3), 212-225. https://doi. org/10.1177/1558689807302811

Mutangi, T., 2011, 'Religion, law and human rights in Zimbabwe', African Human Rights Law Journal 17(2011), 526-545.

Ndlovu-Gatsheni, S.J., 2015, 'Decoloniality in Africa: A continuing search for a new world order', Australian Review of African Studies 36(2), 22-50.

Ngcukana, L. \& Fengu, M., 2018, 'Inside cop killers' horror sex cult', News24, viewed 05 August 2018, from www.news24.com/southafrica/news/inside-cop-killershorror-sex-cult-20180225-3

Ngwenyama, O.K., 1990, 'The critical social theory approach to information systems: Problems and challenges', in H.-E. Nissen, H.K. Klein \& R. Hirschheim (eds.), Information systems research: Contemporary approaches and emergent traditions, pp. 267-280, North Holland, Amsterdam.

Nkoane, M.M., 2010. 'Critical liberatory, inclusive pedagogy: Arguing for a zero defect discourse', Acta Academica 43(4), 111-126.

Owusu-Ansah, S., 2016, 'The role of Circle women in curbing violence against women and girls in Africa', Verbum et Ecclesia 37(2), 1-16. https://doi.org/10.4102/ ve.v37i2.1594

Paoli, L., 2004, 'Organised crime in Italy: Mafia and illegal markets - Exceptions and normality', in C. Fijnaut \& L. Paoli (eds.), Organised crime in Europe: Concepts, patterns and control policies in the European Union and beyond, Part 1, pp. 263302, Springer, Dordrecht.
30tterns and control policient

Paoli, L., 2007, 'Mafia and organised crime in Italy: The unacknowledged successes of law enforcement', West European Politics 30(4) 854-880. https://doi. org/10.1080/01402380701500330

Ponterotto, J.G., 2005, 'Qualitative research in counselling psychology: A primer on research paradigms and philosophy of science', Journal of Counselling Psychology 52(2), 126-136. https://doi.org/10.1037/0022-0167.52.2.126

Republic of South Africa (RSA), 2008, Constitution of the Republic of South Africa viewed 17 March 2018, from www.justice.gov.za/legislation/constitution/ SAConstitution-web-eng-02.pdf

Ryan, J., 1998, 'Critical leadership for education in the post-modern world: Emancipation, resistance and communal action', International Journal of Leadership in Education, Theory and Practice 1(3), 257-278. https://doi. org/10.1080/1360312980010303

SABC, 2016, 'Angels Ministries, E Cape swears to defy constitution', SABC Digital News, viewed 23 March 2018, from https://www.youtube.com/watch?v=qxWPLgA-XrQ

Schilderman, H., 2015, 'The concept of religion: Defining and measuring contemporary beliefs and practices', Journal for the Study of Religion 28(2), 226-229.

Spies, D., 2018, 'Ngcobo massacre: Seven suspects dead after police shoot-out', News24, viewed 12 March 2018, from https://www.news24.com/SouthAfrica/ News/ngcobo-massacre-seven-suspects-dead-after-police-shootout-20180224

Steinvorth, U., 2008, 'On critical theory', Analyse and Kritik 30(2), 399-423. https:// doi.org/10.1515/auk-2008-0204

Stinson, D.W., 2009, 'The proliferation of theoretical paradigms quandary: How one novice researcher used eclecticism as a solution', The Qualitative Report 14(3), 498-523.

Thinane-Epondo, P., 2015, “Con" pastors thrive as Africans become increasingly desperate for miracles', Mail \& Guardian Voices of Africa, viewed 23 July 2015, from http://voicesofafrica.co.za/con-pastors-thrive-africans-becomeincreasingly-desperate-miracles/

VanDeCarr, P., 2003, 'The Jonestown that won't fade away: Twenty-five years later a filmmaker examines the lasting consequences', Harvard Divinity Bulletin Fall, a filmm.

Wiggershaus, R., 1994, 'The Frankfurt school: Its history, theories and political significance', translated by M. Robertson, Exile and Return, The New Republic 3(2), 38-41.

Wœver, O., 2007, 'World conflict over religion: Secularism as a flawed solution', in P. Mouritsen \& K.E. Jørgensen (eds.), Constituting communities: Political solutions to cultural conflict, pp. 208-235, Palgrave Macmillan, London. 